\section{Plant Water Status and Fruit Quality in 'Braeburn' Apples}

\author{
T.M. Mills \\ Department of Plant Science, Massey University, and Environment Group, \\ HortResearch, Palmerston North, New Zealand
}

M.H. Behboudian and P.Y. Tan

Department of Plant Science, Massey University, Palmerston North, New Zealand

B.E. Clothier

Environment Group, HortResearch, Palmerston North, New Zealand

Additional index words. Malus domestica, water stress, sugar accumulation, fruit maturity

\begin{abstract}
Five-year-old 'Braeburn' apple trees (Malus domestica Borkh.) on MM.106 rootstock were studied to determine plant and fruit quality responses to reduced plant water status late in the season. Trees were irrigated or not irrigated. Those not irrigated developed reduced xylem water potential and stomatal conductance from 110 and 132 days after full bloom (DAFB), respectively. However, they showed no reduction in photosynthetic rates. Fruit were harvested at stage 1 (S1), starting 167 DAFB, or stage 2 (S2), starting 180 DAFB. At S1, fruit had higher soluble solids concentrations, enhanced red skin pigmentation, and a tendency for higher sorbitol concentrations. Total soluble sugar concentrations at final harvest showed no difference between treatments, but fruit from the nonirrigated trees showed earlier sugar accumulation during the season. Such fruit also had reduced $\mathrm{Ca}^{+2}$ concentrations at $\mathrm{S1}$ and $\mathrm{S} 2$ relative to those on plants that were irrigated. No incidence of any disorder was found in fruit from either treatment at harvest or after 12 weeks of $0 \mathrm{C}$ storage.
\end{abstract}

Apple production is important in many countries, across a range of differing climatic conditions. In some of these countries, water is often a valuable natural resource. Minimizing water use not only reduces production costs, especially where fertigation is normally practiced but also helps to meet the environmental regulations that many countries are adopting to reduce the leaching of nutrients into ground water. Before reduced irrigation can be adopted as a management strategy, it is important to understand its effect on commercial apple production. Although the effects of deficit irrigation on the vegetative growth of apples have been studied (e.g., Durand, 1990), there is less information on its influence on fruit quality. Previous studies indicate that apple fruit produced during water deficits have lower water content, enhanced fruit color (Drake et al., 1981), increased total soluble solids concentration (TSSC), improved storage quality (Guelfat'Reich et al., 1974), and advanced maturity as indicated by internal ethylene con-

Received for publication 3 Jan. 1994. Accepted for publication 16 June 1994. Mention of trade names does not constitute a guarantee or warranty of the products by Massey Univ. or HortResearch, nor does it imply endorsement of similar commercial products. We gratefully acknowledge the statistical advice of Nihal De Silva and the technical support of Chris Rawlingson and Colin Tod. The cost of publishing this paper was defrayed in part by the payment of page charges. Under postal regulations, this paper therefore must be hereby marked advertisement solely to indicate this fact. centrations (Ebel et al., 1993). However, information on the change in mineral composition is conflicting. Irving and Drost (1987) recorded no differences in $\mathrm{N}, \mathrm{P}, \mathrm{K}^{+}, \mathrm{Mg}^{+2}$, or $\mathrm{Ca}^{+2}$ concentrations with differing irrigation regimes, whereas Guelfat'Reich et al. (1974) reported a general decrease in mineral concentration and a tendency toward a decreased $\mathrm{K}^{+}$ : $\mathrm{Ca}^{+2}$ ratio in fruit from nonirrigated treatments. Our research was done to gain further understanding of the effects of mild water deficit developed late in the season on apple fruit quality. Our hypothesis was that a mild water deficit imposed during the later stages of crop development would not have a negative influence on the fruit quality attributes of 'Braeburn' apples. Water deficit effects on some preharvest factors that may influence postharvest fruit attributes also are reported. 'Braeburn' was used because of its importance as an export cultivar in New Zealand and because it is prone to some internal disorders in which water and nutrients might be implicated.

\section{Materials and Methods}

Five-year-old 'Braeburn' apple trees grown on MM.106 rootstock, trained as central leader, were used over the 1992-93 growing season at Massey Univ., Palmerston North, New Zealand (lat. $40.2^{\circ} \mathrm{S}$, long. $175.4^{\circ} \mathrm{E}$ ). The predominant soil type in the experimental block was a fine sandy loam, which is reasonably free-draining. A total of 24 trees were assigned in pairs to treatments in a completely randomized de- sign (a pair of trees were designated as a plot; total of 12 plots used). There were two treatments: irrigated (control) trees (six plots) that received adequate irrigation to maintain soil moisture close to initial levels and nonirrigated trees (six plots) that received no irrigation throughout the season. Black polythene covers were installed under all trees to exclude rainfall. Cultural practices were the same as for other commercial orchards in the area.

Weekly measurements (five per plot) were made of the soil volumetric water content $(\theta)$ to a 1-m depth, using time domain reflectometry (TDR) equipment (model 1502C; Tektronix, Redmond, Ore.) (Topp and Davies, $1985)$; xylem water potential $\left(\psi_{x}\right)$ taken on eight leaves per plot using a Scholander pressure bomb (Soilmoisture Equipment Corp., Santa Barbara, Calif.); and photosynthesis and stomatal conductance taken on four leaves per plot using a portable gas exchange measurement system (model 6200; LI-COR, Lincoln, Neb.). For leaf measurements, the youngest mature leaves were selected from the currentseason's growth and were in full sun at the collection time. Plant measurements always were taken between 1200 and $1400 \mathrm{HR}$ local time. Plant growth was determined by recording increases in trunk circumference over the season, and total leaf area per tree was measured after fruit harvest using an area meter (model LI 3100; LI-COR). The soil-water retention curve was determined using suction and pressure plate apparatus according to Ahuja and Nielsen's methods (1990).

Fruit samples for quality measurements were collected at 30-day intervals starting 63 days after full bloom (DAFB). Each sample included four fruit per tree, picked from all trees and selected from the middle portion of the canopy. At final harvest, 18 fruit per tree were selected, six from each of the top, middle, and bottom portions of the tree. At this final harvest, trees were strip-picked in two stages. At stage 1 (S1), one tree per plot (12 trees total) was harvested within 3 days to assess the impact of water deficit on fruit maturity, based on color, and other quality attributes mentioned later. Stage 2 (S2) harvest was spread over 2 weeks and started 10 days after $\mathrm{S} 1$ was completed. Trees were strip-picked only when overall fruit color on each tree indicated adequate maturity. Consequently, most nonirrigated trees were harvested earlier than irrigated trees within the 2-week harvest; color development of the former was generally more advanced. The S2 harvest allowed us to evaluate quality attributes on fruit of similar maturity levels, assessed on the basis of color.

At final harvest, the fruit quality attributes measured included color as the mean of two measurements per fruit, using a chroma meter (CR-200; Minolta, Osaka, Japan); soluble solids concentration using an automatic compensation refractometer (ATC-1; Atago, Tokyo); and firmness using a penetrometer (model FT 327 ; R. Bryce, Alfonsine, Italy) mounted on a drill stand with a lever to apply a constant and even pressure to the fruit. Titratable acidity was determined on composite samples of fruit from each tree using an automatic titrator 
(model DL21; Mettler, Greifensee, Switzerland). Samples comprised of six fruit from each position (top, middle, bottom) on each tree were homogenized together. Once homogenized, $1 \mathrm{~g}$ of fruit pulp was mixed with 39 $\mathrm{ml}$ of double-distilled water and titrated with $0.1 \mathrm{~m} \mathrm{NaOH}$ to an endpoint $\mathrm{pH}$ of 7.1. Values are expressed as percent malic acid.

Sugar concentration of samples was determined by high-performance liquid chromatography using a carbohydrate analysis column with a de-ashing guard column (Aminex HPX87C; Life Science Group, Hercules, Calif.). The samples taken throughout the season were composite samples comprised of four fruit per tree from all trees. Those taken at final harvest were composite samples from six fruit from each canopy position. Fruit samples of $0.5 \mathrm{~g}$ were collected from the outer equatorial portion of each fruit. Sample preparation was done according to Pesis et al.'s (1991) method. Once samples immersed in $95 \%$ ethanol had been stored below 0C for $\geq 1$ month and cell components had precipitated, 1-ml aliquots were taken and completely dried using a concentrator (model RH 40-11; Savant Instruments, Farmingdale, N.Y.). Samples then were filtered using $0.3-\mu \mathrm{m}$ nylon membrane filters with $3 \mathrm{ml}$ of Barnstead nano-pure water. Sugar concentrations were determined for the four major sugar groups in apples: fructose, glucose, sucrose, and sorbitol (Chan et al., 1972).
Fruit flesh samples, dried at $70 \mathrm{C}$ for 14 days, were digested with concentrated nitric acid for $\mathrm{Ca}^{+2}, \mathrm{Mg}^{+2}$, and $\mathrm{K}^{+}$determination. An atomic absorption spectrometer (model GBC 904AA; GBC scientific equipment, Dandenong, Victoria, Australia) was used for this purpose. Determinations of $\mathrm{N}$ and $\mathrm{P}$ were by Kjeldehl digestion. Sample collection was identical to that specified for sugar concentration determinations. Fruit dry matter concentration was determined using 25 -g composite samples dried at $70 \mathrm{C}$ for 14 days. Intact harvested fruit were stored for 12 weeks at $0 \mathrm{C}$ for inspection of any possible disorders.

Statistical procedures included analysis of variance and comparison by $t$ test, all performed using SAS software (SAS Institute, Cary, N.C.). Plant data collected during the season were analyzed as a randomized design, with pairs of trees (plots) denoted as individual experimental units. Data on fruit characteristics were analyzed as a split-plot design, with stage of harvest accounting for plot splits. The error term for the model accounted for variation of trees within treatments.

\section{Results and Discussion}

Nonirrigated plots had significantly lower $\theta$ than irrigated plots, and the difference became larger as the season progressed (Fig. 1A). Early season differences in $\theta$ between the two treatments was due to the differences in texture and in depth of the underlying coarse gravel layer between the experimental plots (Clothier, 1976). Little change in $\theta$ was recorded in either treatment before 82 DAFB (Fig. 1A). During the initial 82 days of experimentation, 42 days had some rainfall. The high incidence of rainy days may have reduced transpiration rates and, therefore, prevented significant drying of the root zone, although plastic covers kept the rain from reaching the soil. Irrigation of control trees commenced from $119 \mathrm{DAFB}$, when $\theta$ began to show a decline from the initial values. Irrigated plots were maintained at a $\theta$ of 0.24 to $0.28 \mathrm{~m}^{3} \cdot \mathrm{m}^{-3}$, close to the measured field capacity. In the nonirrigated plots $\theta$ eventually fell to and stabilized at $\approx 0.14 \mathrm{~m}^{3} \cdot \mathrm{m}^{-3}$, which corresponds to a soil water potential of about -1.5 $\mathrm{MPa}$. The roots, therefore, must have been absorbing water from further down the profile beyond the TDR rods, having exhausted the available water in the top $1 \mathrm{~m}$ of soil. Data to substantiate this, however, are unavailable. Values of $\psi_{x}$ for irrigated trees were above -1.3 $\mathrm{MPa}$ throughout the season; while $\psi_{\mathrm{x}}$ for nonirrigated trees ranged between -1.3 and -1.8 $\mathrm{MPa}$ from 110 DAFB through to final harvest (Fig. 1B). No differences in $\psi_{\mathrm{x}}$ were recorded between treatments until 110 DAFB, although there were significant differences in $\theta$ before this date. Both treatments showed similar fluctuation patterns in $\psi_{\mathrm{x}}$ from week to week. Differences $\leq 0.7 \mathrm{MPa}$ were recorded between
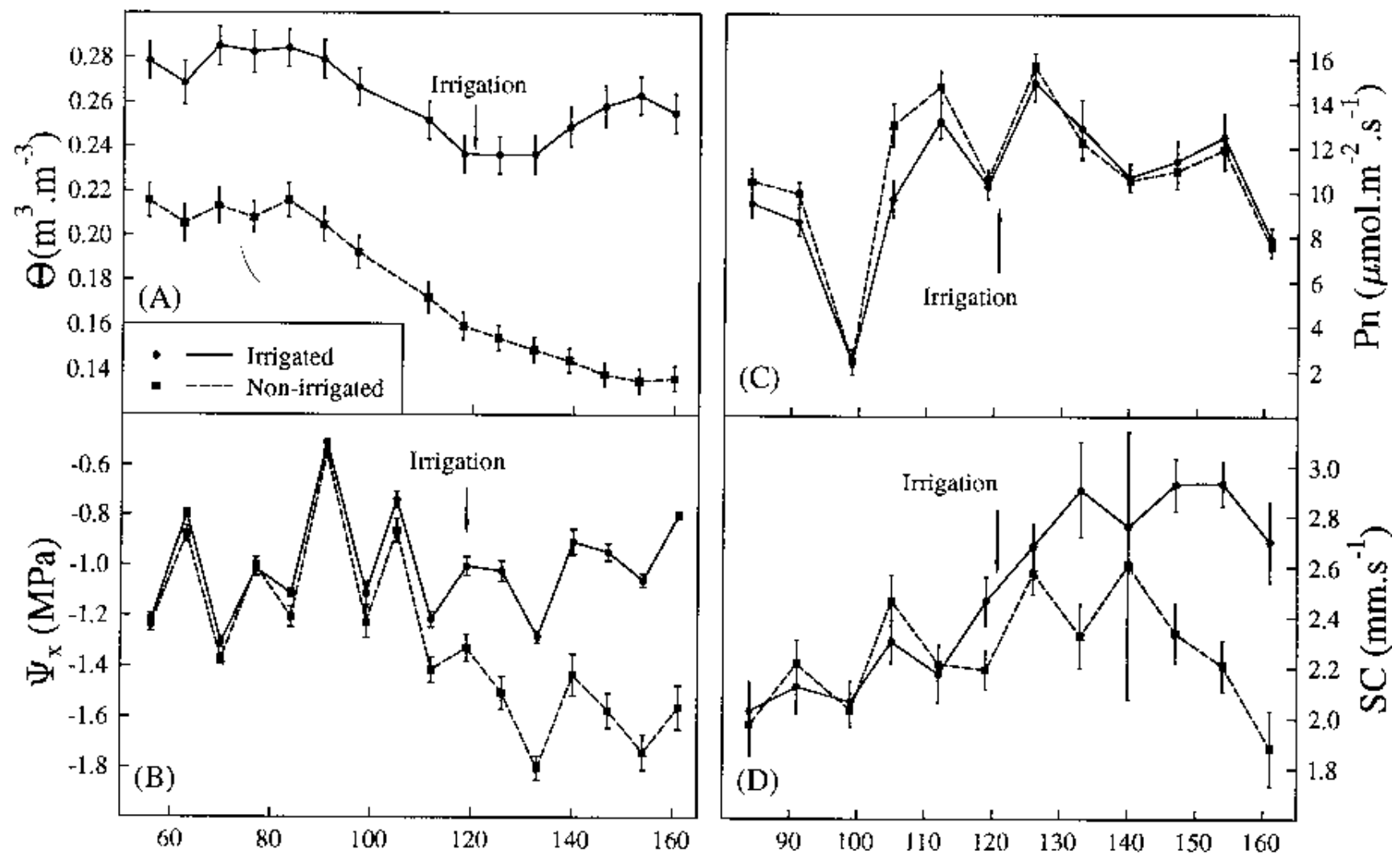

\section{Days after full bloom}

Fig. 1. Changes in soil volumetric water content $(\theta)$, xylem water potential $\left(\psi_{\mathrm{x}}\right)$, net photosynthesis $(\mathrm{Pn})$, and stomatal conductance (SC) during the season for irrigated and nonirrigated 'Braeburn' apple trees. Means $( \pm \mathrm{SE})$ of 30 replications per treatment for $\theta$ and six plot replications (per treatment) for other measurements. 
treatments on any day of measurement from 110 DAFB. These differences might be expected to influence fruit quality attributes at final harvest. Drake et al. (1981) maintained differences of between 0.1 and $0.2 \mathrm{MPa}$ throughout the growing season on 'Golden Delicious' apples and recorded significant differences in fruit color, TSSC, titratable acid- ity, and fruit moisture content between treatments. Up to 140 DAFB, stomata did not respond to the reduced $\theta$ that caused a decrease in $\psi_{\mathrm{x}}$ in nonirrigated trees (Fig. 1D). Thereafter, there was a significant reduction of stomatal conductance, but this did not affect photosynthesis (Fig. 1C).

Some of the measured growth and devel- opment attributes were affected by the stress treatment. There was no significant difference between treatments in total-tree leaf area or trunk growth when initial trunk circumference was used as a covariate. Leaf areas $\left(\mathrm{m}^{2} \pm \mathrm{SE}\right)$ for 10 irrigated and 11 nonirrigated trees were $9.1 \pm 2.4$ and $8.6 \pm 2.3$, respectively. The corresponding increases in trunk circumfer-

Table 1. Effects of water stress on some fruit quality attributes of 'Braeburn' apples at final harvest.

\begin{tabular}{|c|c|c|c|c|c|c|c|c|}
\hline \multicolumn{5}{|c|}{ Total soluble } & \multirow{2}{*}{$\begin{array}{c}\text { Titratable } \\
\text { acidity } \\
(\% \text { malic acid })\end{array}$} & \multirow{2}{*}{$\begin{array}{c}\text { Dry } \\
\text { matter (mg/ } \\
\mathrm{g} \text { fresh wt) }\end{array}$} & \multicolumn{2}{|c|}{ Color } \\
\hline $\begin{array}{l}\text { Harvest } \\
\text { stage }\end{array}$ & Irrigation & $\begin{array}{c}\text { solids } \\
(\%)\end{array}$ & $\begin{array}{l}\text { Mean fruit } \\
\text { wt }(\mathrm{g})\end{array}$ & $\begin{array}{l}\text { Firmness } \\
(\mathrm{N})\end{array}$ & & & $\begin{array}{l}\text { Hue angle } \\
\left({ }^{\circ}\right)\end{array}$ & Lightness $^{2}$ \\
\hline $1^{y}$ & + & $11.0 \pm 0.1^{x}$ & $242 \pm 10.2$ & $55.72 \pm 0.43$ & $0.633 \pm 0.020$ & $140 \pm 2.00$ & $70.5 \pm 2.54^{w}$ & $52.4 \pm 0.690$ \\
\hline & - & $12.0 \pm 0.1$ & $207 \pm 10.2$ & $54.64 \pm 0.43$ & $0.676 \pm 0.020$ & $150 \pm 2.00$ & $59.4 \pm 2.54$ & $50.3 \pm 0.690$ \\
\hline Significance & & $* *$ & $* *$ & $* *$ & NS & $* *$ & $* *$ & $* *$ \\
\hline $2^{\mathrm{v}}$ & $\begin{array}{l}+ \\
-\end{array}$ & $\begin{array}{l}11.8 \pm 0.2 \\
12.5 \pm 0.2\end{array}$ & $\begin{array}{l}257 \pm 15.6 \\
248 \pm 15.6\end{array}$ & $\begin{array}{l}50.22 \pm 0.29 \\
50.52 \pm 0.26\end{array}$ & $\begin{array}{l}0.589 \pm 0.010 \\
0.621 \pm 0.010\end{array}$ & $\begin{array}{l}148 \pm 8.08 \\
155 \pm 6.48\end{array}$ & $\begin{array}{l}55.9 \pm 2.46 \\
50.7 \pm 2.20\end{array}$ & $\begin{array}{l}48.7 \pm 0.770 \\
47.7 \pm 0.750\end{array}$ \\
\hline Significance & & $*$ & NS & NS & $*$ & NS & NS & NS \\
\hline
\end{tabular}

${ }^{2}$ Lightness measured in percent diffuse reflectance \pm SE.

${ }^{y}$ Harvesting from 167 to 170 days after full bloom (DAFB).

${ }^{\times}$Mean (six trees per treatment for Stage 1; four and five trees for irrigated and nonirrigated, respectively, at Stage 2).

${ }^{w}$ Median (six trees per treatment for Stage 1; four and five trees for irrigated and nonirrigated, respectively, at Stage 2) \pm SE.

"Harvesting from 180 to 194 DAFB.

NS, ***Nonsignificant or significant at $P \leq 0.1$ or 0.05 , respectively.

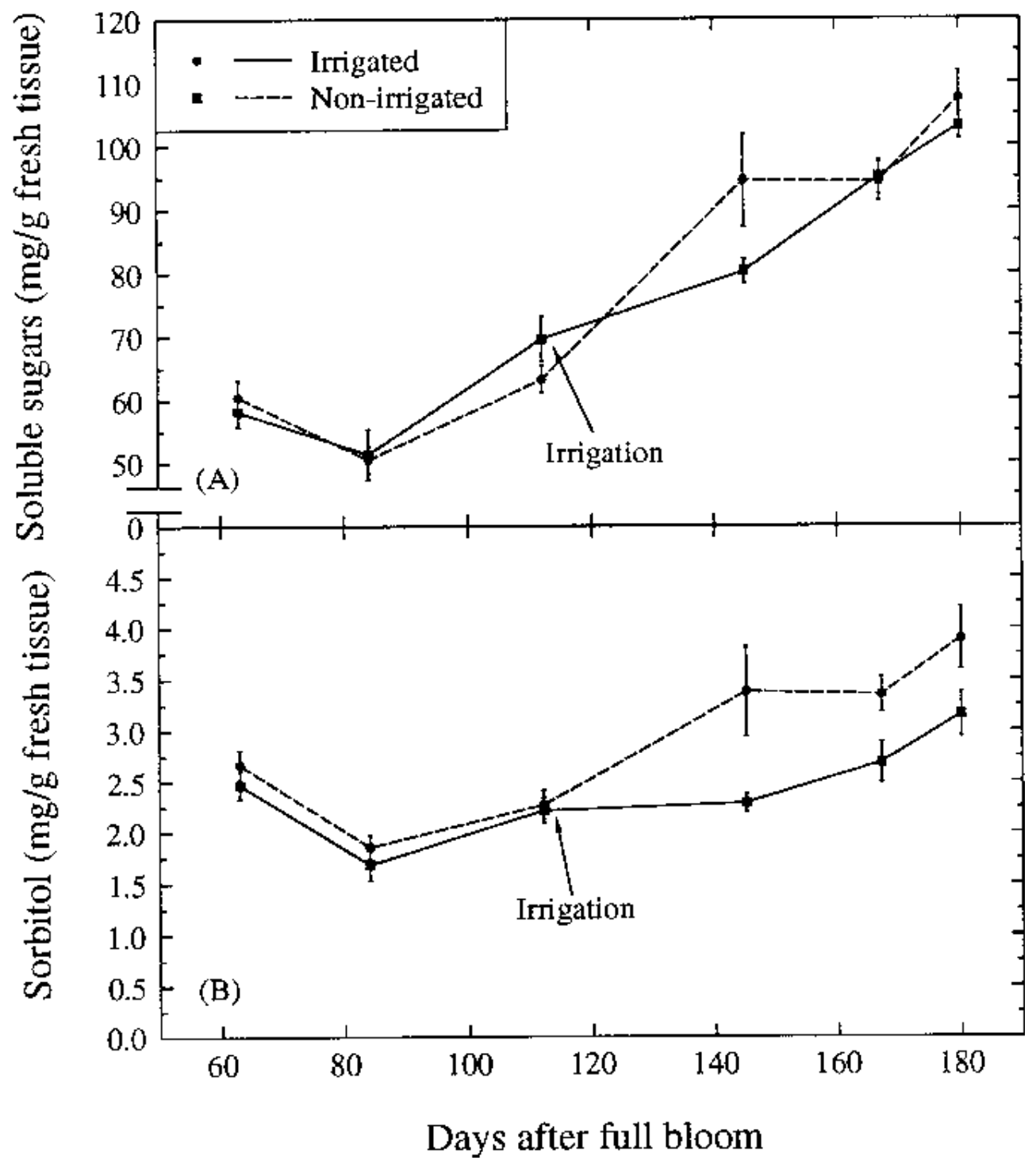

Fig. 2. Total soluble sugar concentration (fructose, glucose, sucrose, and sorbitol) in fruit of 'Braeburn’ apples on irrigated and nonirrigated trees. Means ( \pm sE) of four to six trees (18 fruit per tree). 
ence $(\mathrm{mm} \pm \mathrm{sE})$ were $33.8 \pm 2.0$ and $28.8 \pm 1.9$. A lack of significant difference in the leaf area is explained by the mild soil water deficit developed after shoot growth had ceased at $\approx 95$ DAFB (data not shown). After thinning, the number of fruit was the same on nonirrigated and irrigated trees $(144.3 \pm 14.3$ and $142.0 \pm$ 10.8 , respectively). Fruit dry matter concentration (milligram per gram fresh weight) was lower in irrigated than in the nonirrigated treatment (Table 1). However, mean dry weight per fruit was higher for the irrigated treatment at $\mathrm{S} 1$ and $\mathrm{S} 2(34.41 \pm 0.98$ vs. $31.21 \pm 0.98 \mathrm{~g}$ at $\mathrm{S} 1$ and $41.57 \pm 1.70 \mathrm{vs.} 37.69 \pm 1.25 \mathrm{~g}$ at $\mathrm{S} 2)$. The difference was significant $(P \leq 0.05)$ only at $\mathrm{S} 1$ due to a similarly larger mean fruit weight in the irrigated treatment at S1 (Table 1). Levels of return bloom, recorded during Spring 1993, showed no significant difference in the number of flower clusters recorded between treatments.

Fruit maturity was more advanced in nonirrigated trees. Color and TSSC are established methods of assessing commercial fruit maturity (Kingston, 1991). They are important in consumer preference, affecting appearance (Gorski and Creasy, 1977) and flavor (Krishnaprakash et al., 1983). TSSC in fruit from nonirrigated trees was higher than from irrigated trees at S1 and S2 (Table 1). This difference corresponds to similar differences in fruit dry matter concentration, especially at $\mathrm{S} 1$. At S1, color measured by hue angle indicated redder fruit on nonirrigated trees (Table 1). Hue angle data, however, did not follow a normal distribution. Nonirrigated trees gave a distribution showing a positive skewness (skewed toward redder fruit). Irrigated trees showed a negatively skewed distribution. No difference in color was recorded at S2 (Table 1 ), when maturity based on color was assessed as being the same for all trees. Skin lightness, indicating total absorbed light, also was measured. Dixon (1993) showed a significant correlation between lightness and pigment content. As pigment levels increase, more light is absorbed and lower values of lightness are recorded. No pigment determinations were performed, but significant difference in lightness was recorded only at S1 (Table 1), indicating that nonirrigated fruit had a higher pigment content.

Red pigmentation in apples is predominantly due to anthocyanins in the skin (Salisbury and Ross, 1992). Sugars are impor- tant for anthocyanin production because it is composed of anthocyanidin and sugar complexes (Saure, 1990). Downs et al. (1965) reported that sucrose is required for synthesis of anthocyanin in apple skin. Sucrose concentrations differed in fruit from nonirrigated trees at 145 DAFB; they were (in $\mathrm{mg} / \mathrm{g}$ fresh weight \pm sE) $21.39 \pm 1.77$ and $26.68 \pm 1.69$ for irrigated and nonirrigated treatments, respectively, with values significantly different at $P$ $\leq 0.05$. Also at this time, total sugar concentration was higher in nonirrigated fruit, but by final harvest, this difference had disappeared (Fig. 2A). The increase in red pigmentation in the nonirrigated fruit may be related to a more rapid accumulation of soluble sugars. Earlier sugar accumulation also may be an indicator of advanced maturity.

Carbohydrate accumulation, specifically of sorbitol, is known to contribute to osmotic adjustment in apple leaves (Wang and Stutte, 1992). Wang et al. (1993) reported an enhanced conversion of glucose into sorbitol under water stress in mature apple leaves. In Rosaceae, sorbitol is the major sugar, translocating out of source leaves toward fruit (Faust, 1989). Sorbitol concentrations increased in fruit from nonirrigated trees (Fig. 2B), but the scope of our data does not allow conclusions as to its production site and the possible significance in osmotic adjustment.

Fruit mineral content, specifically $\mathrm{Ca}^{+2}$, has been implicated as an important factor governing fruit storage quality and the incidence of internal fruit disorders, such as bitter pit (Failla et al., 1990). Nonirrigated fruit had similar mineral concentrations as irrigated fruit, except for lower $\mathrm{Ca}^{+2}$ concentrations at $\mathrm{S} 1$ and $\mathrm{S} 2$ and lower $\mathrm{N}$ concentration at S1 (Table 2). Goode and Ingram (1971) found reduced $\mathrm{Ca}^{+2}$ concentrations in fruit from nonirrigated trees, possibly due to lower transpiration rates, as reported by Guelfat'Reich et al. (1974). Tomala and Dilley (1990) suggested that $\mathrm{Ca}^{+2}$ concentrations are related to fruit maturity via the influence of high $\mathrm{Ca}^{+2}$ concentration on the reduction of respiration rate. In their work, fruit with higher $\mathrm{Ca}^{+2}$ concentrations had lower internal ethylene concentrations, which indicated lower maturity levels. This finding is in agreement with the enhanced maturity in fruit from nonirrigated trees.

Concentrations of $\mathrm{N}$ and $\mathrm{P}$ within the fruit have implications for color development. Magness et al. (1940) reported that $\mathrm{N}$ concen- tration may directly influence the red pigment development, while at the same time it may retard the breakdown of chlorophyll in fruit. Increased $\mathrm{P}$ concentration and reduced $\mathrm{N}$ concentration resulted in enhanced color development in 'Golden Delicious' due to a less green pigmentation (Gormley et al., 1973). Goode and Ingram (1971) showed that fruit from irrigated trees had higher $\mathrm{N}$ concentrations than fruit from nonirrigated trees. Reduced $\mathrm{N}$ concentrations in fruit from nonirrigated trees (Table 2) may have contributed to enhanced development of redness. Titratable acidity tended to be higher in nonirrigated fruit at $\mathrm{S} 1$ and S2 (Table 1). Firmness was significantly lower in nonirrigated fruit at $\mathrm{S} 1$ but not at $\mathrm{S} 2$. A reduction in firmness indicates enhanced maturity at S1 (Kingston, 1991).

We conclude that a mild water deficit late in the season improved fruit quality in terms of higher TSSC, enhanced red pigmentation, and earlier accumulation of some soluble sugars. There was less $\mathrm{Ca}^{+2}$ in nonirrigated fruit; however, no fruit disorders were observed at harvest or after 12 weeks of storage at $0 \mathrm{C}$, and there was no effect of deficit irrigation on return bloom.

\section{Literature Cited}

Ahuja, L.R. and D.R. Nielsen. 1990. Field soilwater relations, p. 143-190. In: B.A. Stewart and D.R. Nielsen (eds.). Irrigation of agricultural crops. Madison, Wis.

Chan, W.W., C. Chong, and C.D. Taper. 1972. Sorbitol and other carbohydrate variation during growth and cold storage of McIntosh apple fruits. Can. J. Plant Sci. 52:743-750.

Clothier, B.E. 1976. Moisture retention in a layered soil, p. 18-29. Proc. of Soil and Plant Water Symp., Palmerston North, New Zealand, 25-27 May 1976.

Dixon, J. 1993. Temperature and atmosphere composition influence on colour change of apples. MS Thesis, Massey Univ., Palmerston North, New Zealand.

Downs, R.J., H.W. Siegelman, W.L. Butler, and S.B. Hendricks. 1965. Photoreactive pigments for anthocyanin synthesis in apple skin. Nature 205:909-910.

Drake, S.R., E.L. Proebsting, M.O. Mahan, and J.B. Thompson. 1981. Influence of trickle and sprinkle irrigation on 'Golden Delicious' apple quality. J. Amer. Soc. Hort. Sci. 106:255-258.

Durand, G. 1990. Effects of RDI on apple tree (cv. Royal Gala) growth, yield and fruit quality in a humid environment. PhD Diss., Massey Univ., Palmerston North, New Zealand.

Ebel, R.C., E.L. Proebsting, and M.E. Patterson.

Table 2. Mineral and soluble sugar concentration of 'Braeburn' apples at final harvest as affected by water stress.

\begin{tabular}{|c|c|c|c|c|c|c|c|c|c|c|c|}
\hline \multirow{2}{*}{$\begin{array}{l}\text { Harvest } \\
\text { stage }\end{array}$} & \multirow[b]{2}{*}{ Irrigation } & \multicolumn{5}{|c|}{$\begin{array}{l}\text { Mineral concn } \\
(\mathrm{mg} / \mathrm{g} \text { dry } w \mathrm{t})\end{array}$} & \multicolumn{5}{|c|}{$\begin{array}{c}\text { Soluble sugar concn } \\
(\mathrm{mg} / \mathrm{g} \text { fresh } \mathrm{wt})\end{array}$} \\
\hline & & $\mathrm{N}$ & $\mathrm{P}$ & $\mathrm{K}^{+}$ & $\mathrm{Mg}^{+2}$ & $\mathrm{Ca}^{+2}$ & Fructose & Sucrose & Glucose & Sorbitol & Total $^{\mathrm{z}}$ \\
\hline \multirow[t]{2}{*}{$1^{\mathrm{y}}$} & + & $2.59 \pm 0.2^{y}$ & $0.734 \pm 0.05$ & $8.99 \pm 0.5$ & $0.323 \pm 0.02$ & $0.261 \pm 0.01$ & $48.0 \pm 1.3$ & $33.1 \pm 1.6$ & $11.6 \pm 1.0$ & $2.70 \pm 0.2$ & $95.4 \pm 3.3$ \\
\hline & - & $2.15 \pm 0.2$ & $0.673 \pm 0.05$ & $8.79 \pm 0.5$ & $0.339 \pm 0.02$ & $0.228 \pm 0.01$ & $48.3 \pm 1.3$ & $32.5 \pm 1.6$ & $10.1 \pm 1.0$ & $3.35 \pm 0.2$ & $94.4 \pm 3.1$ \\
\hline Significance & & * & NS & NS & NS & $*$ & NS & NS & NS & $*$ & NS \\
\hline \multirow[t]{2}{*}{$2^{\mathrm{x}}$} & + & $2.20 \pm 0.1$ & $0.658 \pm 0.05$ & $9.63 \pm 0.5$ & $0.349 \pm 0.03$ & $0.324 \pm 0.04$ & $51.1 \pm 1.8$ & $38.9 \pm 1.8$ & $9.90 \pm 0.7$ & $3.15 \pm 0.3$ & $103 \pm 3.9$ \\
\hline & - & $1.93 \pm 0.1$ & $0.619 \pm 0.05$ & $8.69 \pm 0.5$ & $0.289 \pm 0.02$ & $0.196 \pm 0.03$ & $51.6 \pm 1.8$ & $40.4 \pm 1.8$ & $10.7 \pm 0.7$ & $3.87 \pm 0.3$ & $107 \pm 3.9$ \\
\hline Significance & & NS & NS & NS & NS & $* *$ & NS & NS & NS & NS & NS \\
\hline
\end{tabular}

${ }^{2}$ Mean (six trees per treatment for Stage 1, four and five trees for irrigated and nonirrigated, respectively, at Stage 2) \pm SE.

${ }^{y}$ Harvesting from 167 to 170 days after full bloom (DAFB).

${ }^{x}$ Harvesting from 180 to 194 DAFB.

NS, ${ }^{*}, * *$ Nonsignificant or significant at $P \leq 0.1$ or 0.05 , respectively. 
1993. Regulated deficit irrigation may alter apple maturity, quality, and storage life. HortScience 28:141-143.

Failla, O., C.P. Treccani, and I. Mignani. 1990. Water status, growth and calcium nutrition of apple trees in relation to bitter pit. Scientia Hort. 42:55-64.

Faust, M. 1989. Physiology of temperate zone fruit trees. Wiley, New York.

Goode, J.E. and J. Ingram. 1971. The effects of irrigation on the growth, cropping and nutrition of Cox's Orange Pippin apple trees. J. Hort. Sci. 46:195-208.

Gormley, R., D. Robinson, and N. O'Kennedy. 1973. The effects of soil management systems on the chemical composition and quality of apples. I. Golden Delicious apples. J. Sci. Food Agr. 24:227-239.

Gorski, P.M. and L.L. Creasy. 1977. Color development in 'Golden Delicious' apples. J. Amer. Soc. Hort. Sci. 102:73-75.
Guelfat'Reich, S., R. Assaf, B. Bravdo, and I. Levin. 1974. The keeping quality of apples in storage as affected by different irrigation regimes. J. Hort. Sci. 49:217-225.

Irving, D.E. and J.H. Drost. 1987. Effects of water deficit on vegetative growth, fruit growth and fruit quality in Cox's Orange Pippin apple. J. Hort. Sci. 62(4):427-432.

Kingston, C.M. 1991. Maturity indices for apple and pear, p. 407-432. In: J. Janick (ed.). Horticultural reviews vol. 13. Wiley, New York.

Krishnaprakash, M.S., B. Aravindaprasad, C.A. Krishnaprasad, P. Narasimham, S.M. Ananthakrishna, S. Dhanaraj, and V.S. Govindarajan. 1983. Effects of apple position on the tree on maturity and quality. J. Hort. Sci. 58:31-36.

Magness, J.R., L.P. Batjer, and L.O. Regeimbal. 1940. Correlation of fruit color in apples to nitrogen content of leaves. Proc. Amer. Soc. Hort. Sci. 37:39-42.

Pesis, E., P. Long, and E. Hewett. 1991. Composi- tional changes in kiwifruit infected with botrytis cinerea. I. In vivo studies. N.Z. J. Crop Hort. Sci. 19:405-412.

Salisbury, F.B. and C.W. Ross. 1992. Plant physiology. 4th ed. Wadsworth, Belmont, Calif.

Saure, M.C. 1990. External control of anthocyanin formation in apple. Scientia Hort. 42:181-218.

Tomala, K. and D.R. Dilley. 1990. Some factors influencing the calcium level in apple fruits. Acta Hort. 274:481-487.

Topp, G.C. and J.L. Davies. 1985. Time-domain reflectometry (TDR) and its application to irrigation scheduling. Adv. Irr. 3:107-127.

Wang, Z. and G. Stutte. 1992. The role of carbohydrates in active osmotic adjustment in apple under water stress. J. Amer. Soc. Hort. Sci. 117:816-823.

Wang, Z., B. Quebedeaux, Jr., and G. Stutte. 1993. Enhanced conversion of ${ }^{14} \mathrm{C}$-glucose into sorbitol under water stress in mature apple leaves. HortScience 28:166. (Abstr.) 